\title{
IMPROVEMENT OF THE REGIONAL MANAGEMENT SYSTEM BASED ON HARMONIZATION OF INTERESTS OF SOCIAL AND ECONOMIC INTERACTION SUBJECTS
}

\author{
Almaz Sh. Akhmetov ${ }^{1}$ \\ Aidar M. Toufetulov ${ }^{2}$ \\ Gulnara N. Khadiullina ${ }^{3}$ \\ Fatih Sh. Nugaev ${ }^{4}$
}

\begin{abstract}
Activation of the processes on globalization and national economic space regionalization actualizes the problem of formation of an effective mechanism for managing the regional socio-economic system, the availability of which ensures effective use of available resources, creates prerequisites for the formation and implementation of the competitive potential of a territorial entity, and is a necessary prerequisite for neutralizing the consequences of global and local crises. The level of sustainable functioning of regional socio-economic systems is a key factor affecting the socioeconomic development of the Russian economy in the face of
\end{abstract}

increasing uncertainty in the external environment. This requires new approaches to identify tools for new governmental management at the meso level, to developing new forms and models for sustainable socio-economic development of regions. The paper substantiates the thesis that the necessary condition for the implementation of sustainable development of the regional economic system is the presence of adapters in its elements that provide a certain quality of management decisions. Regional development is aimed at achieving a set of parameters that meet the needs of economic agents: residents and non-residents of the regional

\footnotetext{
1 Kazan Federal University. E-mail address: verkbund@gmail.com. Tel.: +7 (906) 3219099.

${ }^{2}$ Kazan Federal University. E-mail address: verkbund@gmail.com. Tel.: +7 (906) 3219099.

${ }^{3}$ Kazan Federal University. E-mail address: verkbund@gmail.com. Tel.: +7 (906) 3219099.

${ }^{4}$ Kazan Federal University. E-mail address: verkbund@gmail.com. Tel.: +7 (906) 3219099.
} 
economy, subject to feasibility of management decision, compliance with strategic guidelines for regional development and reducing agency costs. At the same time, regional development is interpreted as the result of structural changes (the synthesis of structure and processes) in the system of interaction between subjects of socioeconomic relations at the meso level, and controlling is considered as a tool for effective management of innovation changes.

Keywords: regional economy, interaction between subjects of social and economic interaction, mesoeconomic indicators, strategic analysis, new governmental management.

\section{Introduction}

Sustainable development of a particular region, along with the action of general laws on the functioning and development of a national economy, has its own specifics and is determined by the share of production of basic industries in a region in total production in the country, the availability of the export sector in the regional economy, the level of security and the availability of the regional resource potential, the mentality of the population, etc. However, along with these factors which determine the necessary prerequisites for progressive mesoeconomic dynamics and its configuration, there are sufficient conditions, including conditions of the regional management system which determines the completeness and effectiveness level of the resource potential implementation as a factor of sustainable development. In turn, the effectiveness of management decisions largely depends on complete accounting for the nature of interactions in the regional system of socio-economic relations with the participation of the state, business and society.

Increasing the level of uncertainty in the external environment and the complexity of the management system necessitate formation of an effective internal coordination mechanism. Controlling in the strategic management system of sustainable regional development ensures the transformation of regional system development goals into a system of targeted programs. At the same time, it is 
viewed as a tool that allows for monitoring and analysis of actual deviations based on the definition of planned parameters for regional development, organization of interaction between information flows within the mesoeconomic system, monitoring of the main processes implemented within the system, taking into account the space and time characteristics, and evaluation of results.

\section{Methods}

According to the regional management interpretation by Gavrilov A.I., a territory is considered as a corporation formed by territorial entities united by a common goal and unity of location $[1 ; 35]$. These entities include agents of socio-economic processes in the region, which interact and are connected with various formal and informal relations; the list of those agents can include the regional government considered as a full-fledged subject of economic activity and, at the same time, the subject of the public management structure in the form of which indirect influence occurs through the creation of a set of certain administrative, legal, economic conditions that constitute an entrepreneurship climate.

In our opinion, effectiveness of functioning of a public administration system in a region can be improved on the basis of improving the mechanism that harmonizes the interests of the social and economic interaction subjects, taking into account the entrepreneurial and creative components. Accordingly, it is necessary to establish a balance between expectations and opportunities, authority and responsibility. We consider it expedient to set positions for the economic responsibility areas of regional governments, the society and business, as well as to determine the area of their mutual interests and shared responsibility (Fig. 1). 


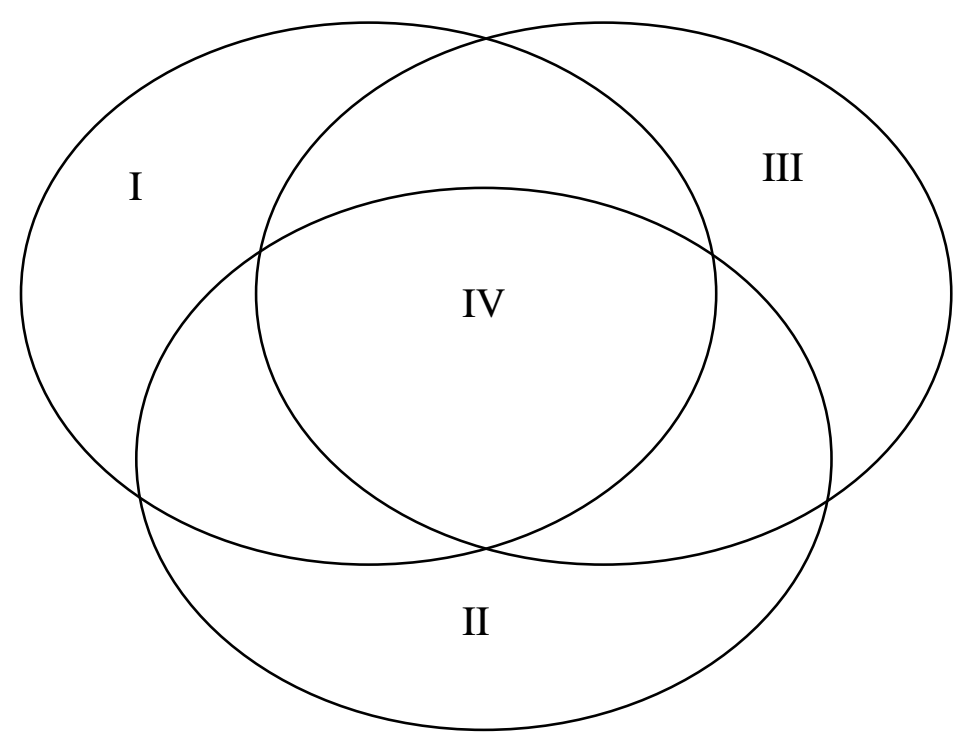

Fig. 1. Venn diagram to identify the area of mutual interests and responsibilities of regional government, population and business [2; 28]

Zone I - interests and responsibilities of regional governments.

Zone II - interests and responsibilities of the society (local community).

Zone III - interests and responsibilities of regional business.

Zone IV - joint interests and mutual responsibility.

These conditions actualize the use of foreign experience for controlling systems. Dieter Khan, a professor at the Berlin Technical University and JustusLiebig University in the city of Giessen, defines controlling as "... an informational support of the resultsbased management of an enterprise" [6; 23]. However, in our opinion, controlling is a broader concept, and it includes a complete process of setting and achieving goals, which allows to consider controlling as a "profit management system". In modern management, the objectives of a region are divided into operational and tactical, which, in turn, allows us to subdivide controlling depending on its objectives into operational and tactical controlling, 
the characteristics of which are presented in Table 1.

Table1: Characteristics of controlling types at the regional level

\begin{tabular}{|c|c|c|}
\hline Features & Strategic controlling & Operational controlling \\
\hline Orientedness & $\begin{array}{l}\text { Internal and external regional } \\
\text { environments }\end{array}$ & $\begin{array}{l}\text { Indicators of economic } \\
\text { efficiency and profitability of } \\
\text { regional enterprises }\end{array}$ \\
\hline Control & Strategic & Tactical and operational \\
\hline Goal & $\begin{array}{l}\text { Anti-crisis policy, survival, } \\
\text { potential for success }\end{array}$ & $\begin{array}{l}\text { Budget profitability, earning } \\
\text { power and liquidity of } \\
\text { regional enterprises }\end{array}$ \\
\hline Main goals & $\begin{array}{l}\text { Definition of regional goals; } \\
\text { Development of a strategy for } \\
\text { social and economic } \\
\text { development; } \\
\text { Identification of alternative } \\
\text { development options; } \\
\text { Identification of critical } \\
\text { points that determine } \\
\text { strategic plans; } \\
\text { Identification of key } \\
\text { indicators on compliance } \\
\text { with the normative ones } \\
\text { within the framework of } \\
\text { defined strategies; } \\
\text { Estimation of economic } \\
\text { efficiency }\end{array}$ & $\begin{array}{l}\text { Development of Guidelines } \\
\text { for current and operational } \\
\text { budget planning; } \\
\text { Identification of the } \\
\text { conditions for tactical control; } \\
\text { Identification of a set of key } \\
\text { indicators on compliance with } \\
\text { current objectives; } \\
\text { Identification of the reasons } \\
\text { for the deviations of actual } \\
\text { indicators from the normative } \\
\text { ones; } \\
\text { Assessment of the impact of } \\
\text { identified deviations on } \\
\text { current planning; }\end{array}$ \\
\hline
\end{tabular}




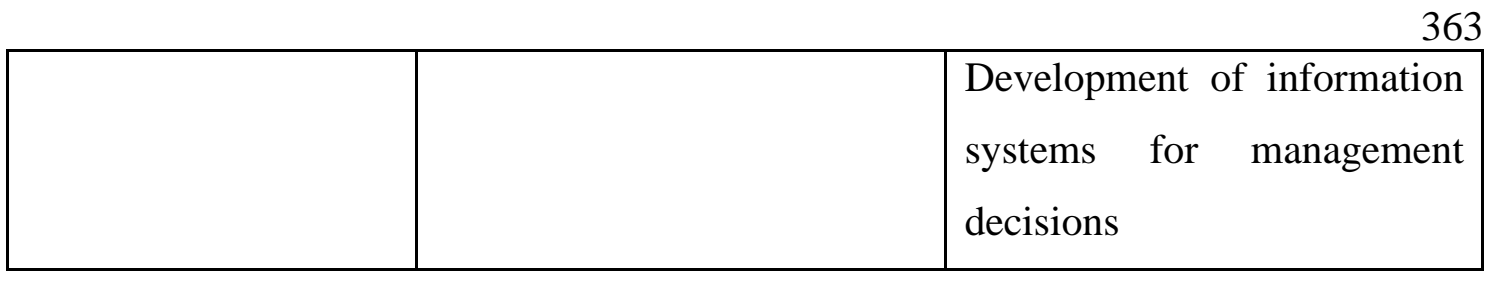

With the help of strategic controlling, the formation of a regional economic strategy is ensured, short-term goals are realized with the help of operational control, and current (operative) solutions for optimizing the revenue and expenditure parts of regional budgets are adopted.

\section{Results}

In our opinion, the structure of regional controlling as a process of planning and monitoring results at the regional level should include:

1. Regional development strategy, which comprises a general goal of the regional development as a direction of socioeconomic activity of the region;

2. Regional strategic planning, being implemented as a special type of management activities in the direction of the development strategy, which is a set of the main objectives of the region and options for their achievement;

3. Operational planning at the regional level is represented by a management system for the implementation of goals identified at the level of strategic planning and allows for the continuity of the decision-making process in the area of regional resources movement and optimization of revenue and expenditure parts of regional budgets;

4. Management accounting, a feature of which is the focus on the information needs of the regional leadership on the adoption of managerial decisions;

5. Monitoring of information flows at the regional level reveals the features of the processes occurring in the region and provides operational reports on the results of work. Monitoring can be graphically represented in the form of a block diagram (Fig. 2).

6. Analysis of the results and criteria for decision-making is carried out on the basis of all the above stages, which identify strategic alternatives, choose the most expedient of them, and start a new economic cycle on the basis of an objective assessment of the current situation, analysis of the potential and prospects for development, [5; 129]. 


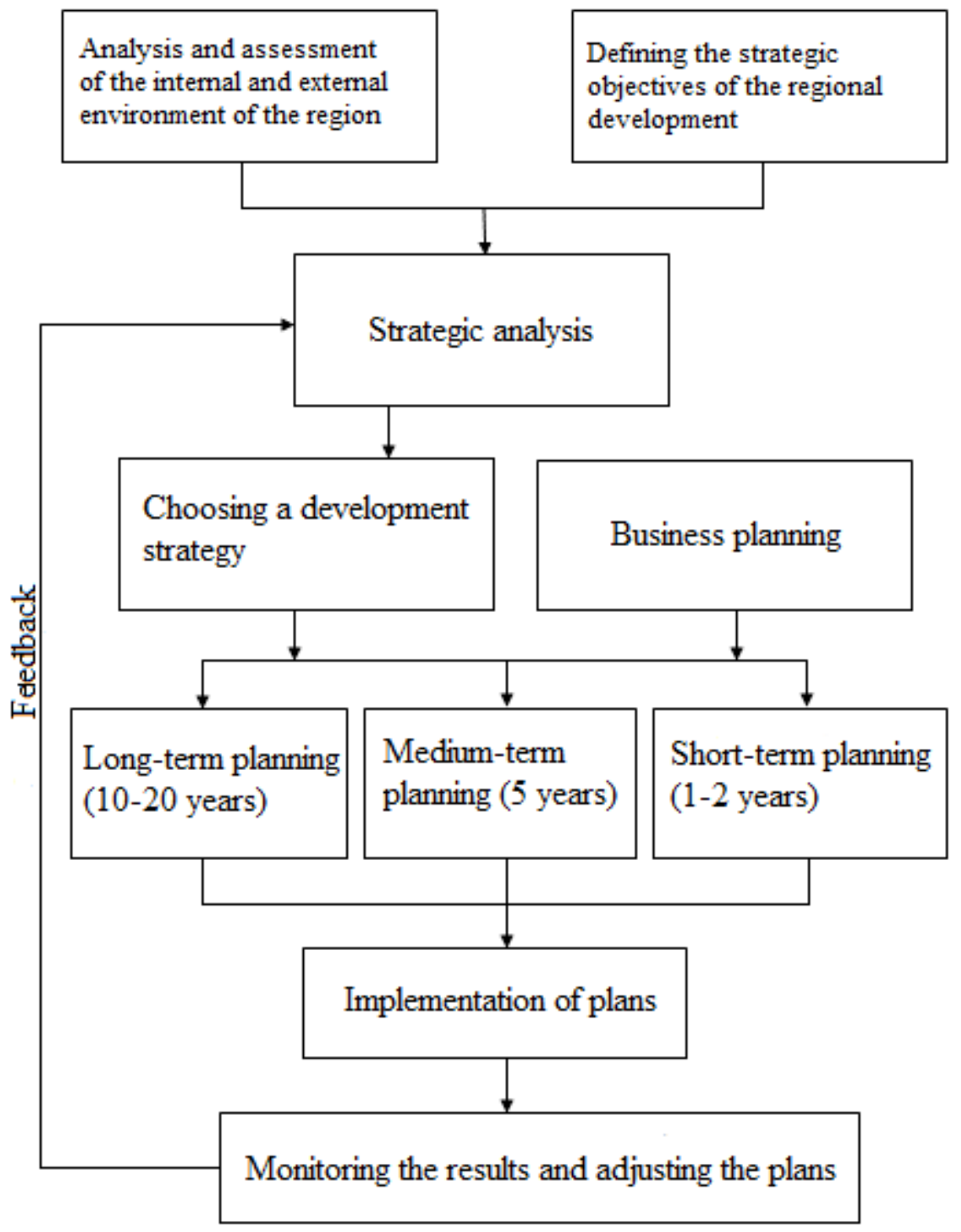

Fig. 2. Algorithm for monitoring regional information flows

The cluster analysis of Russian regions was carried out based on the data of the official state statistics bodies of the Russian Federation, taking into account, on the one hand, the indicators of the social and economic development of the territories, and, on the other hand, the quality of controlling within these territorial entities $[3 ; 4]$. As a result of hierarchical clustering, five main types of regions (clusters) were identified (Table 2). 
Periódico do Núcleo de Estudos e Pesquisas sobre Gênero e Direito Centro de Ciências Jurídicas - Universidade Federal da Paraíba

V. 8 - No 04 - Ano 2019 - Special Edition ISSN | 2179-7137 | http://periodicos.ufpb.br/ojs2/index.php/ged/index

Table2:The final centers of clusters (groups of regions)

\begin{tabular}{|c|c|c|c|c|c|}
\hline \multirow{2}{*}{$\begin{array}{l}\text { Indicator of the } \\
\text { regional development }\end{array}$} & \multicolumn{5}{|c|}{ Number and characteristics of the cluster } \\
\hline & 1 & 2 & 3 & 4 & 5 \\
\hline $\begin{array}{l}\text { 1. Population, } \\
\text { thousand people. }\end{array}$ & 1726.15 & 514.13 & 50.76 & $3,725.55$ & 43.39 \\
\hline $\begin{array}{l}\text { 2. Per capita income, } \\
\text { thousand rubles / } \\
\text { person }\end{array}$ & 48214.53 & 308919.61 & 421415.29 & 160376.81 & 440243.15 \\
\hline $\begin{array}{l}\text { 3. Unpaid income per } \\
\text { capita, thousand rubles } \\
\text { / person }\end{array}$ & 14477.37 & 8737.39 & 204353.45 & 37414.81 & 97977.60 \\
\hline $\begin{array}{l}\text { 4. Share of expenses on } \\
\text { wages, } \%\end{array}$ & 12.74 & 11.77 & 9.19 & 11.96 & 16.82 \\
\hline 5. Subsidies, mln. rub. & $7,701.46$ & 332.68 & 8953.49 & 16049.14 & 0.00 \\
\hline $\begin{array}{l}\text { 6. Subsidies, million } \\
\text { rubles. }\end{array}$ & 5111.86 & 2145.00 & 758.28 & 2887.82 & 104.21 \\
\hline $\begin{array}{l}\text { 7. Subventions, million } \\
\text { rubles. }\end{array}$ & 3549.57 & 1110.76 & 314.13 & 8443.87 & 4077.61 \\
\hline $\begin{array}{l}\text { 8. Expenditures per } \\
\text { capita }\end{array}$ & 51915.94 & 283370.90 & 440114.79 & 168985.57 & 455148.76 \\
\hline $\begin{array}{l}\text { 9. Budget deficit / } \\
\text { surplus in the region, } \\
\text { mln. rubles }\end{array}$ & $\begin{array}{l}-5435 . \\
57\end{array}$ & 12573.20 & -949.17 & $\begin{array}{l}-14020 . \\
39\end{array}$ & -646.78 \\
\hline $\begin{array}{l}10 . \quad \text { Quality of } \\
\text { controlling in the } \\
\text { region, share }\end{array}$ & 0.58 & 0.67 & 0.64 & 0.63 & 0.64 \\
\hline
\end{tabular}

For the first cluster, hierarchical management systems are characterized by a relatively low level of characteristic, which require substantial controlling and budget deficits, rigid modernization. For the second cluster, 


\section{Periódico do Núcleo de Estudos e Pesquisas sobre Gênero e Direito \\ Centro de Ciências Jurídicas - Universidade Federal da Paraíba \\ V. 8 - No 04 - Ano 2019 - Special Edition}

ISSN | 2179-7137 | http://periodicos.ufpb.br/ojs2/index.php/ged/index

characterized by a relatively high level of controlling and budget surplus, adaptive management systems are characteristic, which make it possible to use a selforganization potential. The distinctive features of the third cluster are the medium level of quality controlling, a small budget deficit and a high level of per capita income associated with its insignificant number; the regions of the fourth and fifth clusters have similar indicators.

\section{Discussion}

Let us explore the types of potential strategies for regional application:

1. Commodity strategy consisting in the conditions of the organization of potential commodity markets corresponding to regional needs, which determines the requirements for the most preferable regional areas of activity, ensuring the improvement of living standards of the population.

2. The strategy of formation and regulation of production, financial and labor resources market; the strategy consists in the formation of principal theses which have an active influence on the effectiveness of the demand formation for regional resources.

3. The strategy of coherence with the financial regional market, which is the elaboration of rules and norms for the formation of additional financial resources needed for both investment tasks and for solving current financial problems.

4. The strategy of stimulating labor resources, which forms a "motivational field" that increases the efficiency of using labor capital and satisfies the requirements of the regional market.

5. The strategy of reducing production and transaction costs, developing the mainstream of regional provisions and providing regional competitive advantages by reducing costs with developing principles for regulating the costs formation process.

6. Transaction cost strategy which forms databases on potential transaction partners, and develops cost-effective regulations for the preparation and implementation of various market transactions.

7. The strategy of foreign economic activity of the region, which determines the principles for the implementation of export-import 
operations on the basis of federal and regional legislation.

8. The investment activity strategy, which forms the investment portfolio of the region and is directly related to innovative regional activities, and involves determining the direction on maintaining the level of material security of the region with a constant demand for goods and services.

9. The strategy of preventing insolvency (bankruptcy) of enterprises in the region, contributing to the forecasting of its consequences and the definition of strategic decisions within the framework of the above strategies.

Diagnostics for weak signals is required in the case of a high level of regional instability, the scale of which assessment is shown in Table 3, where more instability corresponds to a greater number of points.

Table 3 :Determination of factors and levels of instability

\begin{tabular}{|c|c|c|c|c|c|c|}
\hline \multirow[b]{2}{*}{ Characteristics } & \multicolumn{6}{|l|}{ Stages } \\
\hline & Stability & $\begin{array}{l}\text { Reaction to } \\
\text { problems }\end{array}$ & Foresight & \multicolumn{2}{|c|}{ Study } & Creation \\
\hline $\begin{array}{l}\text { Event } \\
\text { customization }\end{array}$ & Habitual & $\begin{array}{l}\text { Within the } \\
\text { extrapolation } \\
\text { of } \\
\text { experience }\end{array}$ & \multicolumn{3}{|c|}{$\begin{array}{l}\text { Unexpected, but having } \\
\text { analogies in the past }\end{array}$} & $\begin{array}{l}\text { Unexpected } \\
\text { and } \\
\text { completely } \\
\text { new }\end{array}$ \\
\hline Rate of change & $\begin{array}{l}\text { Slower } \\
\text { than the } \\
\text { reaction of } \\
\text { a firm }\end{array}$ & \multicolumn{3}{|c|}{$\begin{array}{l}\text { Compared with the reaction of } \\
\text { a firm }\end{array}$} & \multicolumn{2}{|c|}{ Faster than reaction } \\
\hline $\begin{array}{l}\text { Predictability } \\
\text { of the future }\end{array}$ & $\begin{array}{l}\text { By } \\
\text { analogy } \\
\text { with the } \\
\text { past }\end{array}$ & $\begin{array}{l}\text { By } \\
\text { extrapolation }\end{array}$ & $\begin{array}{l}\text { Predictabl } \\
\text { problems } \\
\text { opportunit }\end{array}$ & anc & $\begin{array}{r}\text { serious } \\
\text { new }\end{array}$ & $\begin{array}{l}\text { Partial } \\
\text { predictability } \\
\text { for weak } \\
\text { signals }\end{array}$ \\
\hline \multicolumn{7}{|c|}{ Scale of instability } \\
\hline points & 1 & 2 & 3 & & 4 & 5 \\
\hline
\end{tabular}




\section{Periódico do Núcleo de Estudos e Pesquisas sobre Gênero e Direito \\ Centro de Ciências Jurídicas - Universidade Federal da Paraíba \\ V. 8 - No 04 - Ano 2019 - Special Edition}

ISSN | 2179-7137 | http://periodicos.ufpb.br/ojs2/index.php/ged/index

There are five levels of awareness:

I. There are weak signals about changes in the external environment, but there is no certainty in their parity;

II. The certainty of the sources of changes and their orientation is increasing;

III. Specification of the scale, scope and nature of the changes;

IV. The ways of solving the problem have been identified, but there is no certainty in the consequences of the decisions made;

V. A high probability of predictability and certainty of the results of decisions taken to eliminate the danger.

Consequently, the timely response to signals from the external and internal regional environment requires the organization within the control system of monitoring a large sample of the parameters of the living conditions in the region, which also actualizes the formation of monitoring which includes:

- list of observed target parameters for assessing the region's activities;

- principles of quantitative and qualitative evaluation of external and internal signals;
- frequency of observation of established parameters;

- methods for analyzing the possible consequences of initial economic phenomena identified in the process of observation;

- methods for determining the "critical points" in chains of economic phenomena and the procedure for monitoring these points;

- principles of developing anti-crisis management decisions based on observations and economic analysis;

- the order of the listed sections essentially reflects the order in the package of measures for scanning the external and internal environments of an enterprise and the development of management decisions on this basis.

A high level of instability, determined by a dynamic change in the internal and external situation, causes the rate of change which exceeds the response to these changes, and actualizes the need for strategic decisions when weak signals from the external environment arise. The action matrix is shown in Table 4. 
Table 4:Matrix of regional actions in conditions of weak signals

\begin{tabular}{|c|c|c|c|c|c|c|}
\hline \multirow[b]{2}{*}{$\begin{array}{l}\text { The } \\
\text { strength of } \\
\text { signals } \\
\text { from the } \\
\text { external } \\
\text { environme } \\
\text { nt }\end{array}$} & \multicolumn{6}{|c|}{ The nature of measures to increase effectiveness } \\
\hline & $\begin{array}{l}\text { Monitori } \\
\text { ng of the } \\
\text { environm } \\
\text { ent }\end{array}$ & $\begin{array}{l}\text { Determinat } \\
\text { ion of the } \\
\text { relative } \\
\text { strength of } \\
\text { the signal }\end{array}$ & $\begin{array}{l}\text { Reducing } \\
\text { external } \\
\text { strategic } \\
\text { vulnerabil } \\
\text { ity }\end{array}$ & $\begin{array}{l}\text { Increasin } \\
\mathrm{g} \\
\text { intraregio } \\
\text { nal } \\
\text { flexibility }\end{array}$ & $\begin{array}{l}\text { Implementat } \\
\text { ion of } \\
\text { preliminary } \\
\text { measures }\end{array}$ & $\begin{array}{l}\text { Practic } \\
\text { al } \\
\text { activiti } \\
\text { es }\end{array}$ \\
\hline $\begin{array}{l}\text { Potential } \\
\text { hazards }\end{array}$ & & & & & & \\
\hline $\begin{array}{l}\text { Definitene } \\
\text { ss of the } \\
\text { threat or } \\
\text { possibility }\end{array}$ & & & & & & \\
\hline $\begin{array}{l}\text { Definitene } \\
\text { ss of the } \\
\text { problem } \\
\text { scale }\end{array}$ & & & & & & \\
\hline $\begin{array}{l}\text { Definitene } \\
\text { ss of the } \\
\text { solution to } \\
\text { the } \\
\text { problem }\end{array}$ & & & & & & \\
\hline $\begin{array}{l}\text { Predictabi } \\
\text { lity of the } \\
\text { results of } \\
\text { decisions }\end{array}$ & & & & & & \\
\hline
\end{tabular}

The table presented illustrates the possibility of taking countermeasures in connection with the increase in the amount of information about signals, which corresponds to the tasks of controlling weak signals. 


\section{Periódico do Núcleo de Estudos e Pesquisas sobre Gênero e Direito \\ Centro de Ciências Jurídicas - Universidade Federal da Paraíba \\ V. 8 - No 04 - Ano 2019 - Special Edition}

ISSN | 2179-7137 | http://periodicos.ufpb.br/ojs2/index.php/ged/index

Precautionary reaction facilitates the adoption of timely actions to eliminate potential crisis phenomena, which makes the strategic controlling tool relevant and applicable in controlling regional management.

\section{Summary}

Thus, controlling within the regional management structure is a complex system linking the setting of goals, planning, accounting, monitoring, analysis, management of information flows and developing recommendations for making managerial decisions, which ensures the synthesis of the regional dynamic development over time with the complexity in identifying and solving regional problems.

\section{Conclusions}

The cluster analysis for the Russian regions based on accounting for, on the one hand, indicators of the social and economic development of the territories, and, on the other hand, the quality of controlling within these territorial entities, made it possible to identify five main types of regions (clusters). A comparative analysis of clusters of regions has shown that the level of quality of controlling largely determines the dynamics of social and economic development indicators of the region, and, at the same time, these indicators depend on the chosen model of regional management and the level of using the self-organization potential. This circumstance determined the need for research of key parameters, the change of which indicates a change in the possible level of use of the selforganization potential analyzed within the framework of a dissertation study based on the controlling quality indicator.

\section{Acknowledgments}

The work is performed according to the Russian Government Program of Competitive Growth of Kazan Federal University.

\section{Bibliography}

A.I. Gavrilov Regional economy and management. N. Novgorod: Publishing house VVAGS, 2002. 239 p. 
A.S. Kuzichev Venn diagrams. History and applications. Moscow: Nauka, 1968. 249 p.

Official site of the Federal Service of State Statistics. Free access. http://www. gks.

ru/wps/wcm/connect/rosstat_main/rosst at/en/statistics/accounts/ Accessed date: August 25, 2017.

Social Atlas of the Russian Regions. // Free access. http://www. socpol. ru/maps/kris_36_01. gif Accessed date: 08. 25. 2017.
A.M. Tufetulov, A. Sh. Akhmetov. On the strategies of spatial development of regions // Bulletin of Kazan State Power Engineering University. 2017. №1 (33).
P. $127-134$

Khan D. P\&C: Planning and control: the concept of controlling. - Moscow:

Finance and Statistics, 1997. 765 p 